International Journal of Agriculture, Environment and Bioresearch

Vol. 5, No. 05; 2020

ISSN: $2456-8643$

\title{
PADDY PRODUCTION IN MALAYSIA: A FLEXIBLE RISK STOCHASTIC FRONTIER PRODUCTION FUNCTION ANALYSIS
}

\author{
Yahaya Kaka ${ }^{* 1}$, Mad Nasir Shamsudin ${ }^{2}$, Ismail Abd. Latif ${ }^{2}$ and Alias Radam ${ }^{3}$ \\ ${ }^{1}$ Department of Agricultural Economics \& Extension, Faculty of Agriculture, Kebbi State University of Science \& \\ Technology, Aliero, P.M.B 1144 Kebbi State, Nigeria \\ ${ }^{2}$ Department of Agribusiness and Bio-resource Economics, Faculty of Agriculture, Universiti Putra Malaysia, 43400 \\ UPM Serdang Malaysia \\ ${ }^{3}$ Department of Management and Marketing, Faculty of Economics and Management, Universiti Putra Malaysia, \\ 43400 UPM Serdang, Malaysia
}

https://doi.org/10.35410/IJAEB.2020.5555

\begin{abstract}
This study investigates production risk and technical inefficiency as two possible sources of the production variability that characterized Malaysian Paddy Production. Data from a total of 397 Paddy farms randomly sampled from Muda Agricultural Development Authority (MADA) were used for the analysis. The study used a trans-log stochastic frontier production function model with flexible risk specification. The empirical estimates revealed that, mean output is positively influenced by seed, fertilizer, agrochemicals and labour. Fertilizer and agrochemicals are found to be risk-reducing inputs, while seed and labour are revealed to be risk-increasing inputs. This implies that an average risk-averse producer is expected to use more of fertilizer and agrochemicals and less of seed and labour compared to risk-neutral producer in the study area. It was also revealed that extension visit, credit access, MR219 seed variety, MR220CL2 seed variety, method of broadcasting and harvesting technology significantly reduces the technical inefficiency of producers. Average technical efficiency of Paddy farms was found to be 83.6 percent indicating that a potential exist for improving paddy output in the study area.
\end{abstract}

Keywords: Paddy, Production Risk, Just and Pope, Technical Inefficiency, MADA.

\section{INTRODUCTION}

Paddy farming is one of the most important activities in Malaysian Agriculture sector. Paddy (rice) is a crucial part of everyday Malaysian diet. Thus according to [1], the crop enterprise was recently identified as the most important food crop in Malaysia for ensuring the nation`s food security. Paddy is the most important cultivated crops, besides oil palm and rubber in the country, covering a total land area of about 684,545 ha in 2012 [2]. It is mostly cultivated in the eight major designated producing areas called Granary Areas. The granary areas which cover over 200,000 hectares of the irrigated paddy land are found in Peninsular Malaysia. The mini granary areas with irrigation facilities totally about 28,000 hectares are also found all over the country. The granary Areas, which support both main-season and off-season paddy productions, provide about $72 \%$ of the rice production in the country [3]. 
Historically, Malaysia has never meet self-sufficiency level with respect to paddy production the highest level achieved was 92\% during the third Malaysian plan ([4]. The Ministry of Agriculture and Agro-based Industry, in an attempt to achieve higher self-sufficiency level and food security, adopted $4^{\text {th }}$ National Agricultural Policy, which is now called the National Agrofood Policy 2011-2020. This policy is targeting at making the country to attain $85 \%$ self sufficiency level in rice production by developing large scale paddy farming in Sabah and Sarawak through private sector investment and sector modernization. However, the overall production of rice does not satisfy the country`s need, the country therefore resorts to importation of rice to augment deficit (gap) between consumption and domestic production in the country fig.(1).

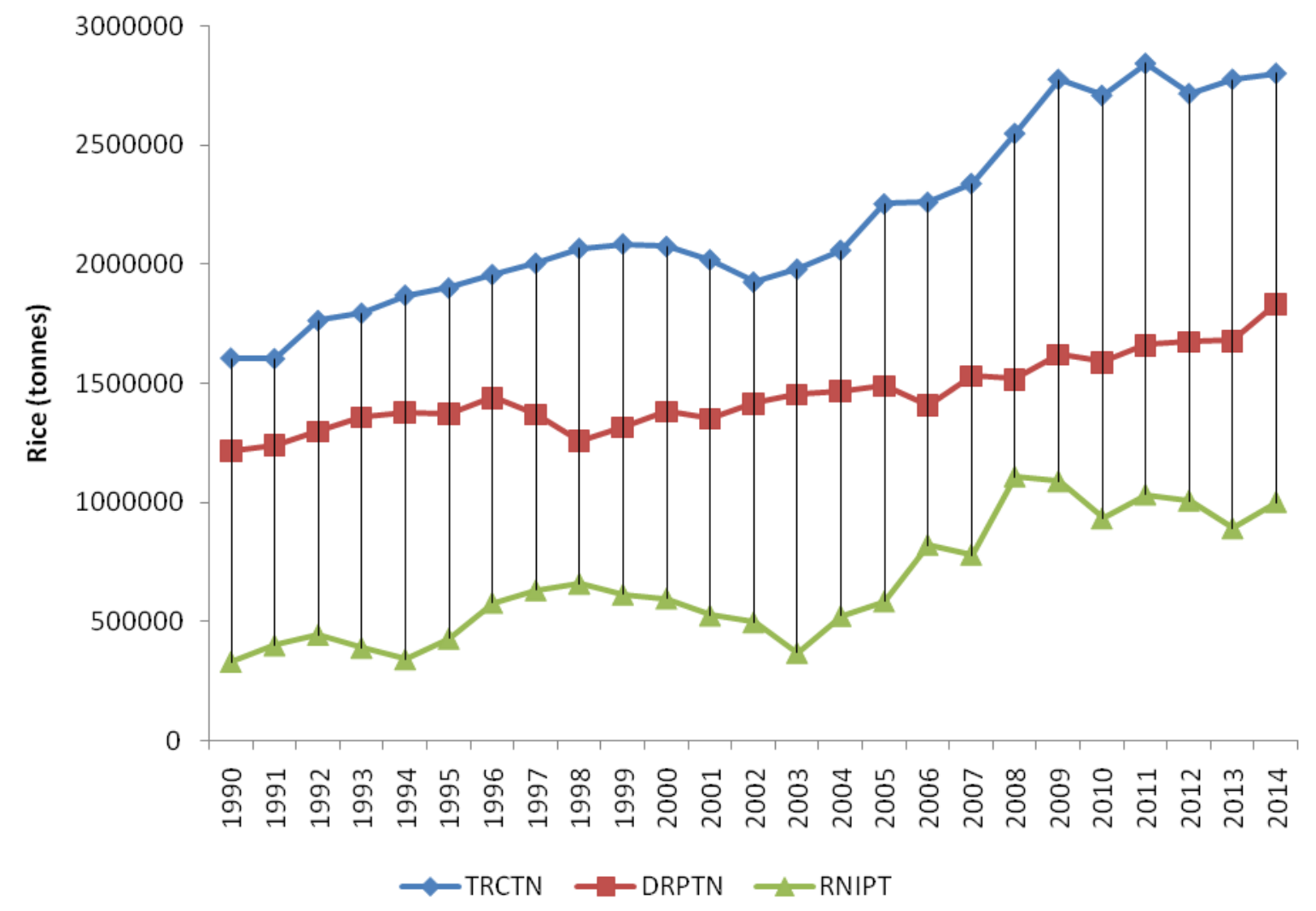

Figure 1: Malaysia Rice Consumption, Domestic Production and Net Import, 1990-2014

Note: TRCTN (Total Rice Consumption); DRPTN (Domestic Rice Production); and, RNIPT (Rice Net Import).

Source: Time-series Data- Department of Statistics Malaysian (2015) and World Rice Statistics Online Query Facility-IRRI

Paddy farming in Malaysia is inherently operated with risk emanating from weeds, pests and diseases, inadequate supply of quality seed, extension support and intensive management 
practices. Others include limited opportunities for credit and the presence of technical inefficiency, which was identified by previous studies [5];[6]; and [7] focusing on this sector as indispensable for sustainable paddy production. Despite the importance of paddy in the nation`s farming system, actual paddy yield in MADA was low (4.5 t/ha) when compared to potential yield of $10 \mathrm{t} / \mathrm{ha}$ in the country reported by [6] and continue to fluctuate due to increasing diseases, pests and soil fertility decline.

The presence of risk influences not only production output but also producers' behaviour, primarily with regard to input use. Therefore, technical efficiency assessed considering a producer's response to uncertainty is not the same in a setting where no effect of risk on input use decisions is taken into account. Thus, the theoretical framework for studying technical efficiency needs to be extended to incorporate risk in the estimations of farmer's technologies. In this study, production risk is assumed to be an important factor in paddy production and to influence production decisions of paddy farmers. Hence, the present study aims to estimate the extent of both technical inefficiency and production risk faced by paddy producers in the study area.

\section{MATERIAL AND METHODS}

\subsection{Study Area}

The study was conducted in Muda Agricultural Development Authority (MADA) located in the north-west of peninsular Malaysia. MADA covers two Malaysian States that comprise Kedah and Perlis with a total area of 126,000 hectare which includes towns, forest and swamp areas. Area irrigated for paddy double cropping is 95,856 hectares of which $80.66 \%$ is located in the State of Kedah and 19.34\% in the State of Perlis [7]. For easy administration MADA was divided into four regions and through the concept of area development the four regions was further divided into 27 localities (figure 2). 


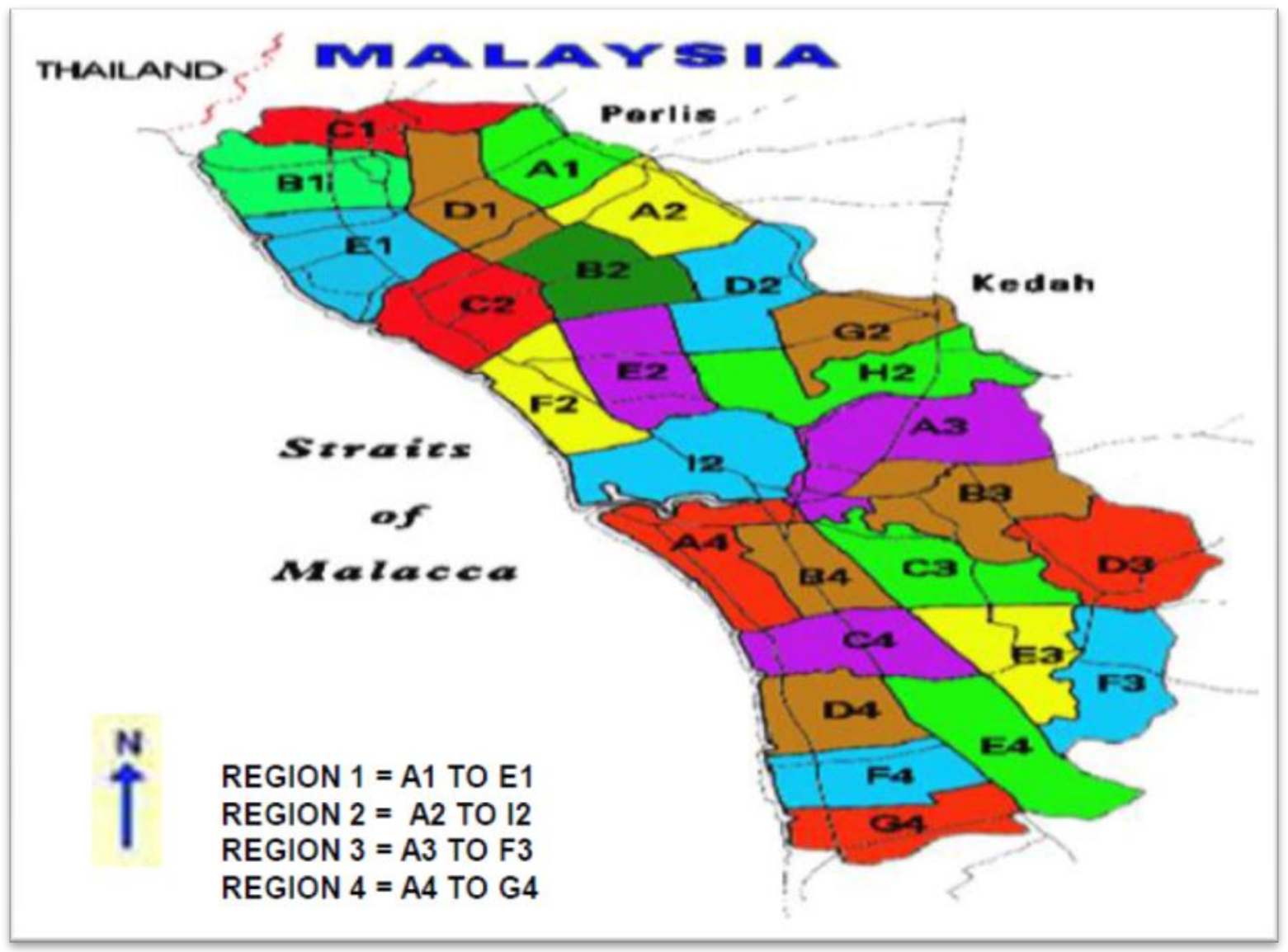

Figure 2: Study Area Source: Rafidah (2011)

About 49,300 farmers are cultivating paddy in the study area either with state of sole ownership of land or renting [9]. MADA area accounts for $40 \%$ of national paddy production and $22 \%$ of paddy cultivation area in the country.

\subsection{Data Collection}

A structured questionnaire was used to collect primary quantitative input-output data from a sample of 397 households. Information on socio-economic variables such as age, education, farming experience, extension contact, credit used, planting method, broadcasting method, use of high yield variety, agrochemicals and harvesting method were also collected.

\subsection{Sampling Techniques}

The registers of the participating paddy farmers from MADA granary authority constituted a sampling frame. The four regions were taken as the sampling units as a first stage of sampling. At the second stage localities were randomly selected from each region to represent the region. The last stage involved random selection of paddy farmers in each locality making a total of 397 respondents. 
Vol. 5, No. 05; 2020

ISSN: $2456-8643$

\subsection{Data Analysis}

Atrans-log functional form of stochastic Frontier Production Function with Flexible Risk Specification was employed to analyse: mean production function, variance production function and inefficiency production function using a single stage estimation procedure of Frontier version available in Stata12 Software.

\subsection{Theoretical Framework}

A stochastic frontier analysis which requires a parametric representation of the production technology was employed in this research. In addition it incorporates stochastic output variability by means of a two-part error term. This approach was pioneered independently by [10] and [11]. The general notation of the model is as follows:

$y_{i}=f\left(x_{i} ; \alpha\right) \exp \left(\varepsilon_{\mathrm{i}}\right)(1)$

Where: $\mathrm{y}_{\mathrm{i}}$ is output of producer $\mathrm{i}$ (bounded above by the stochastic component $\left(\mathrm{x}_{\mathrm{i}} ; \alpha\right) \exp \left(\mathrm{v}_{\mathrm{i}}\right), \mathrm{x}_{\mathrm{i}}$ is vector of inputs used by producer $\mathrm{i}, \alpha$ is a vector of unknown technology parameters, $\left(\mathrm{x}_{\mathrm{i}} ; \alpha\right)$ is production frontier. The composed error term is $\varepsilon_{i}=v_{i}-u_{i}$. Wherevi captures the effect of pure noise in the data attributed to measurement error, extreme weather conditions etc. and $\mathrm{u}_{\mathrm{i}}$ is onesided error that captures the inefficiency effects.

However, the conventional specification of a stochastic production function has a feature that may seriously restrict its potential to depict production technology appropriately. An important disadvantage of traditional multiplicative stochastic specification of production technology is the implicit assumption that, if any input has a positive effect on output, then a positive effect of this input on output variability is also imposed. [12]illustrates that, the effects of inputs on output should not be tied a priori to the effects of inputs on output variability. The authors therefore, proposed a more general stochastic specification model that includes two general functions: one that specifies the effects of the inputs on the mean output and another that specifies the effects of input on the variance of output specified as:

$y_{i}=f\left(x_{i} ; \alpha\right)+g\left(z_{i} ; \Psi\right) v_{i}(2)$

Where $\left(\mathrm{x}_{\mathrm{i}} ; \alpha\right)$ reveals the mean production function and $\left(\mathrm{z}_{\mathrm{i}} ; \Psi\right)$ represents the stochastic component which reflects the relationship between the level of input and variability of output. The $\alpha$ and $\Psi$ are mean production function and variance production function parameters and $\mathrm{v}_{\mathrm{i}}$ is a stochastic term assumed to be i.i.d. $\mathrm{N}(0,1)$. The variables $Z$ are used to explain output variability and can be identical to the input variable $\mathrm{x}$. As a result, an input $\mathrm{x}_{\mathrm{i}}$ can have differing influence both on anticipated output level and on output variance since in this case the expected output is given by $\mathrm{E}(\mathrm{y})=f(\mathrm{x} ; \alpha)$, and the variance by $\mathrm{V}(\mathrm{y})=\mathrm{V}(\varepsilon)=\mathrm{g}^{2}(\mathrm{z} ; \Psi)$. Appropriately the effect of inputs has been separated into two effects: the effect on mean and the effect on variance. The marginal influence of an input $x_{i}$, that is the partial derivative of the variance with respect to this input, can therefore be positive(risk increasing input), negative(risk reducing input) or zero(risk neutral input).

[13] additively incorporate the structure of the conventional SFA model independently proposed by [10] and [11] into [12] model. This yield an SFA model with flexible risk specification as: $y_{i}=f\left(x_{i} ; \alpha\right)+g\left(Z_{i} ; \Psi\right)\left[v_{i}-u_{i}\right](3)$

Where $\mathrm{y}_{\mathrm{i}}, \mathrm{x}, f(\mathrm{x} ; \alpha), \mathrm{g}(Z ; \Psi)$ and $\mathrm{v}_{\mathrm{i}}$ are as defined above. The $\mathrm{u}_{\mathrm{i}}$ is the error term that captures technical inefficiency as $\delta_{\mathrm{u}}^{2}=(w)$. The introduction of $\mathrm{u}$ in [13] model differentiate it from 
[12]model, which is the trademark of the SFA model. However, the problem of [13] equation is that it imposes the same variable inputs, as well as a functional form on the heteroskedasticity in $\mathrm{v}$ and $\mathrm{u}$.

[14] extended [13] model by generalizing the model to allow the effects of the variable inputs and functional form to differ on the heteroskedasticity in $\mathrm{v}$ and $\mathrm{u}$. A generalized [14] SFA model with a flexible risk specification is specified as:

$y_{i}=f\left(x_{i} ; \alpha_{\mathrm{i}}\right)+g\left(Z_{\mathrm{i}} ; \Psi_{\mathrm{i}}\right) v_{i}-q\left(w_{\mathrm{i}} ; \delta_{\mathrm{i}}\right) u_{i}(4)$

Where $\mathrm{q}(w ; \delta)$ is an additional function introduced to captures the effects of farmer's socioeconomic variables on the technical inefficiency effects, which also allows for heteroskedasticity in inefficiency error term $\mathrm{u}$ as $\delta_{\mathrm{u}}{ }^{2}=q(w)$.

According to equ. (5) which is in line proposed by [15], technical efficiency (TE) is measured by ratio of the observed output given its value of inputs and inefficiency effect to the frontier output is given by:

$T E_{i}=\frac{E\left(Y_{i} / X_{i}, U_{i}\right)}{E\left(Y_{i} / U_{i}=0\right)}=\frac{f\left(X_{i} ; \alpha_{i}\right)-g\left(X_{i} ; \Psi_{i}\right) U_{i}}{f\left(X_{i} ; \alpha_{i}\right)}=1-\frac{u g\left(X_{i} ; \Psi_{i}\right)}{f\left(X_{i} ; \alpha_{i}\right)}$ (5)

Technical inefficiency (TI) is represented as;

$T I_{i}=\frac{u g\left(X_{i} ; \Psi_{i}\right)}{f\left(X_{i} ; \alpha_{i}\right)}$ (6)

The technical efficiency therefore becomes;

$T E_{i}=1-T I_{i}(7)$

From equ. (6) it can be seen that TI depends positively upon the production risk function and negatively on mean output if there is no inefficiencies. This indicates that TE is also dependent upon production risk. It is therefore important to incorporate production risk into stochastic frontier model.

The conventional stochastic frontier model on the other hand proposes that TE is dependent on one-sided random error only, $\mathrm{TE}_{\mathrm{i}}=\exp \left(-\mathrm{u}_{\mathrm{i}}\right)$. In multiplicative form of conventional stochastic frontier model, TE is given by;

$T E_{i}=1-U \frac{f\left(X_{i}\right)}{f\left(X_{i}\right)}(8)$

$T I_{i}=U \frac{f\left(X_{i}\right)}{f\left(X_{i}\right)}=U_{i}(9)$

Technical inefficiency however, does not depend upon only the input levels as in equ. 8. For this study production risk is accounted for in its estimation of TE as in equ. 5. The equation adjusts the TE scores depending on the effects of inputs on production risk which allows unbiased estimates of TE to be obtained.

\subsection{Empirical Model Specification}

The trans-log function is the most frequently used flexible function in production studies [16]. This study therefore employed Trans-logstochastic production function model using quadratic form with flexible risk specification as follows: 
$\operatorname{In} P_{j}=\alpha_{0}+\sum_{i=1}^{4} \alpha_{i} \operatorname{In} x_{i}+0.5 \sum_{i=1}^{4} \alpha_{i i} \operatorname{In} x_{i}^{2}+\sum_{i=1}^{4} \sum_{k=1}^{4} \alpha_{i k} \operatorname{In} x_{i} \operatorname{In} x_{k}+\varepsilon_{j}(10)$

Where the stochastic disturbance term, $\varepsilon_{\mathrm{i}}$, is presented as:

$\varepsilon_{j}=h\left(\chi_{;} \Psi\right) v_{i}-q(\omega ; \delta) u_{i}(11)$

$h(x ; \Psi) v_{\mathrm{i}}$ Is the risk function component, $q(w ; \delta) \mathrm{u}_{\mathrm{i}}$ Is the technical inefficiency function component, $p_{i}$ is the quantity of paddy produced by $\mathrm{j}$-th farmer measured in $\mathrm{kg} / \mathrm{ha}, \mathrm{x}_{1}$ is quantity of seed used measured in $\mathrm{kg} / \mathrm{ha}, \mathrm{x}_{2}$ is quantity of fertilizer used measured in $\mathrm{kg} / \mathrm{ha}, \mathrm{x}_{3}$ is quantity of agrochemicals used measured in lt/ha, $x_{4}$ is labour used measured in man days/ha, $j$ is $j$-th farmer where $\mathrm{j}=1,2,3, \ldots, 397$ and $\mathrm{i}$ is $\mathrm{i}$-th input where $\mathrm{j}=1,2, \ldots, 4$ and $\alpha_{0}, \alpha_{\mathrm{i}}, \alpha_{\mathrm{ii}}$ and $\alpha_{\mathrm{ik}}$ are the estimated parameters of production technology.

With the reference to the risk function component (equ. 11), the linear production risk function is specified as:

$h\left(x_{i} ; \Psi\right) v_{\mathrm{i}}=\Psi_{0}+\sum_{w=1}^{4} \Psi_{w} \operatorname{In} x_{w}(12)$

Where: $\mathrm{X}_{\mathrm{i}}$ `s represent input variables, $\mathrm{v}_{\mathrm{i}}$ `s is pure noise effects, $\Psi_{0}$ `s and $\Psi_{\mathrm{w}}$ `s are the estimated risk model parameters, $\mathrm{x}_{\mathrm{W}}$ `s are vectors of $\mathrm{w}$ producer technological variables, $\mathrm{x}_{1}$ is amount of seed used measured in $\mathrm{kg} / \mathrm{ha}, \mathrm{x}_{2}$ denotes quantity of fertilizer measured in $\mathrm{kg} / \mathrm{ha}, \mathrm{x}_{3}$ is agrochemicals used measured in lt/ha and $\mathrm{x}_{4}$ is labour used measured in man days/ha. The input variable that is seed, fertilizer, agrochemicals and labour can either decrease output variance or increase it. Thus, $\Psi_{\mathrm{w}}$ s are the marginal production risks of individual inputs and when it is positive it implies that the respective input is a risk increasing input (increases output variance). However, when $\Psi_{\mathrm{w}}$ becomes negative it indicates that the respective input is risk reducing (reduces output variance).

According to inefficiency function component (equ. 11), the linear technical inefficiency model is specified as follows:

$\mathrm{q}\left(\mathrm{w}_{\mathrm{i}} ; \delta_{\mathrm{i}}\right) \mathrm{u}_{\mathrm{i}}=\delta_{0}+\sum_{\mathrm{r}=1}^{15} \delta_{\mathrm{r}} \mathrm{w}_{\mathrm{r}}(13)$

where $u_{i}$ `s are inefficiency effects, $\delta_{\mathrm{r}}$ `s are estimated coefficients of technical inefficiency model and $\mathrm{w}_{\mathrm{r}}{ }^{`} \mathrm{~s}$ are vectors of $\mathrm{r}$ producer technological/socioeconomic variables that consists of age $\left(\mathrm{w}_{1}\right)$ measured in years, education $\left(\mathrm{w}_{2}\right)$ measured in years, marital status $\left(\mathrm{w}_{3}\right)$ measured as dummy $(1=$ married, $0=$ single $)$, household $\operatorname{size}\left(\mathrm{w}_{4}\right)$ measured in number, farming experience $\left(\mathrm{w}_{5}\right)$ measured in years, extension contact $\left(\mathrm{w}_{6}\right)$ measured in number, credit access $\left(\mathrm{w}_{7}\right)$ measured as dummy $(1=$ access, $0=$ no access $)$, farm location $\left(\mathrm{w}_{8}\right)$ measured as dummy $(1=$ Perlis, $0=$ Kedah $)$, land cultivation technology $\left(\mathrm{w}_{9}\right)$ measured as dummy( $1=$ tractor, $0=$ others $)$, MR219 seed variety $\left(\mathrm{w}_{10}\right)$ measured as dummy( $1=\mathrm{MR} 219,0=$ otherwise $), \mathrm{MR} 220 \mathrm{CL}-2$ seed variety $\left(\mathrm{w}_{11}\right)$ measured as dummy( $1=$ MR220CL, $0=$ otherwise $)$ planting technology $\left(\mathrm{w}_{12}\right)$ measured as dummy $(1=$ broadcasting, $0=$ transplanting $)$, broadcasting technology $\left(\mathrm{w}_{13}\right)$ measured as 
dummy $(1=$ machine, $0=$ manual $)$, agrochemical technology $\left(\mathrm{w}_{14}\right)$ dummy $(1=$ used, $0=$ not used $)$ and harvesting technology $\left(\mathrm{w}_{15}\right)$ also dummy $(1=$ machine, $0=$ manual $)$.

\section{RESULTS AND DISCUSSION}

\subsection{Elasticity and Return to Scale}

The estimates of elasticity of output with respect to inputs of production are presented in Table 3.The parameters of the stochastic frontier model revealed that all the output elasticity are positive. The positive sign means that as the variable is increased output increased and the negative sign indicates that as the input is increased output will decrease. The output elasticity for seed, fertilizer, agrochemicals and labour are 0.279 percent, 0.437 percent, 0.113 percent and 0.394 percent respectively. The implication of this is that fertilizer has the highest contribution to paddy production, followed by labour, seed and lastly agrochemical. A percent increase in agrochemicals employed per hectare will increases yield by 0.113 percent and vice versa. The finding is consistence with study of [17], [18] and [7].

Table 3: Maximum likelihood Estimates for Parameters of the Trans-log Stochastic Frontier production model

\begin{tabular}{|c|c|c|c|c|}
\hline Variable & Parameter & Coefficient & Std. Error & P-Value \\
\hline Constant & $\alpha_{0}$ & $2.563^{* * *}$ & 0.336 & 0.000 \\
\hline Seed & $\alpha_{1}$ & $0.279^{* *}$ & 0.116 & 0.017 \\
\hline Fertilizer & $\alpha_{2}$ & $0.437^{*}$ & 0.234 & 0.064 \\
\hline Agrochemicals & $\alpha_{3}$ & 0.113 & 0.201 & 0.574 \\
\hline Labour & $\alpha_{4}$ & $0.394^{* *}$ & 0.168 & 0.019 \\
\hline $1 / 2 *(\text { Seed })^{2}$ & $\alpha_{11}$ & 0.084 & 0.106 & 0.425 \\
\hline $1 / 2 *(\text { Fertilizer })^{2}$ & $\alpha_{22}$ & $-0.257^{* *}$ & 0.106 & 0.015 \\
\hline $1 / 2 *(\text { Agrochemicals })^{2}$ & $\alpha_{33}$ & $0.546^{* * *}$ & 0.192 & 0.005 \\
\hline $1 / 2 *(\text { Labour })^{2}$ & $\alpha_{44}$ & $0.286^{* *}$ & 0.141 & 0.042 \\
\hline (Seed)(Fertilizer) & $\alpha_{12}$ & -0.077 & 0.086 & 0.370 \\
\hline (Seed)(Agrochemicals) & $\alpha_{13}$ & -0.065 & 0.108 & 0.547 \\
\hline (Seed)(Labour) & $\alpha_{14}$ & -0.128 & 0.118 & 0.280 \\
\hline (Fertilizer)(Agrochemical) & $\alpha_{23}$ & -0.372 & 0.101 & 0.713 \\
\hline (Fertilizer)(Labour) & $\alpha_{24}$ & $0.326^{* *}$ & 0.131 & 0.011 \\
\hline (Agrochemicals)(Labour) & $\alpha_{34}$ & $-0.380^{* *}$ & 0.156 & 0.015 \\
\hline \multicolumn{5}{|l|}{ Variance Parameters } \\
\hline Sigma-Squared(u) & & 0.0736 & & \\
\hline Sigma-Squared(v) & & 0.0250 & & \\
\hline $\operatorname{Lambda}\left(\lambda=\delta_{\mathrm{u}} / \delta_{\mathrm{v}}\right)$ & & 2.94 & & \\
\hline $\operatorname{Sigma}^{2}\left(\delta^{2}=\delta v^{2}+\delta u^{2}\right)$ & & 0.006 & & \\
\hline $\operatorname{Gamma}\left(\gamma=\lambda^{2} /\left(1+\lambda^{2}\right)\right)$ & & 0.896 & & \\
\hline
\end{tabular}

Source:Field Survey, 2016. Note: $*, * *$ and $* * *$ denote significance at $10 \%, 5 \%$ and $1 \%$ level respectively. 
Result from this study reveals that a percent increase in quantity of seed used per hectare results in output increase by 0.279 percent. This implies that the optimum quantity of seed to be utilized has not yet been reached thus, increasing seed usage in the study area will increase yield. The result is in conformity with study of [19], [16]. One percent increase in quantity of fertilizer applied per hectare according to the finding will result in the increase of output by 0.437 percent. This means that the increase usage of fertilizer increases output positively. [20] has found similar result on fertilizer in their study. A subsequent percent increase in labour will result in output increase by 0.394 percent. This highlights the importance of labour in the realizing of paddy output. The labour estimate is similar to the finding of the study conducted by [21].

Table 4: Output Elasticity estimates for inputs in the Stochastic Frontier Production Function

\begin{tabular}{|ll|}
\hline Variable & Elasticity \\
\hline Seed & 0.279 \\
Fertilizer & 0.437 \\
Agrochemicals & 0.113 \\
Labour & 0.394 \\
\hline Returns to Scale(RTS) & 1.223 \\
\hline
\end{tabular}

Source:Field Survey, 2016

The sum of the elasticity otherwise known as return to scale (RTS), also called the function coefficient or total output elasticity of 1.223 was obtained from the analysis. The total output elasticity capture the joint proportional contribution of the factor inputs on production. The economic interpretation of the captured RTS is that as all inputs jointly increase by $1 \%$, paddy output increases by about $1.223 \%$. The 1.223 value is greater than 1 and hence according to estimates, paddy production in the study area is characterized as increasing returns to scale. Paddy producers in the study area can still increase all factor inputs by $1 \%$. This will result in output increased by 1.223 which is greater than the proportionate increase in the input factors.

\subsection{Estimatesof Marginal Output Risk}

One important advantage of the [12] approach is the possibility of distinguishing between an input effect on mean output and its impact on output variability that is risk. Output variability in the production process has been explained by the input factors. Some of the inputs are risk reducing while others are risk increasing and this provides vital information to stabilize paddy output. The marginal output risk estimates of the inputs are presented in Table 5. 
International Journal of Agriculture, Environment and Bioresearch

Vol. 5, No. 05; 2020

ISSN: $2456-8643$

Table 5: Marginal Production Risk estimates for Variance Function

\begin{tabular}{|lllll|}
\hline Variables & Parameter & Coefficient & Std. Error & P- Value \\
\hline Constant & $\Psi_{0}$ & $-10.493^{* * *}$ & 3.591 & 0.003 \\
InSeed & $\Psi_{1}$ & 2.458 & 1.857 & 0.186 \\
InFertilizer & $\Psi_{2}$ & $-1.095^{* *}$ & 0.445 & 0.013 \\
InAgrochemicals & $\square_{3}$ & $-2.372^{*}$ & 1.228 & 0.054 \\
InLabour & $\square$ & 0.208 & 1.458 & 0.886 \\
\hline
\end{tabular}

Source: Field Survey, 2016.Note: *, ** and ***, denote significance at 10\%, 5\% and $1 \%$ levels.

Averagely, it can be seen that seed and labour are risk increasing where as fertilizer and agrochemicals are risk decreasing. These results imply that seed and labour are estimated to increase the variance of the value of output; therefore, they need to be treated with caution. Fertilizer and agrochemicals use reduces output variability. This entails that effective use and proper management of fertilizer and agrochemicals can be used to reduce output variance. The result for seed and labour being risk increasing is consistent with study done by [22], [16] and [23] respectively. Fertilizer and agrochemicals also being risk reducing is consistent with work of [24] and [16] respectively. Theoretically speaking, the findings implies that an average riskaverse farmer in this study is expected to employ less of seed and labour due to the ability of these inputs to cause high fluctuations in output and go ahead to use more of fertilizer and agrochemicals compare to a risk- neutral farmer in order to reduce output volatility.

\subsection{Estimates for parameters of inefficiency effects model}

The inefficiency parameters were specified as those relating to farmers`specific socio-economic characteristics, institutional and technological factors. Eleven out of fifteen variables used in the model have expected signs and six of them are significant. A negative coefficient indicates that the variable increases the efficiency (reduces inefficiency) in paddy production and vice versa. The results of the technical inefficiency effects presented in Table 6 shows that technical inefficiency is reduced significantly with education, farming experience, extension visit and access to credit. Similarly, we found that land cultivation technology, MR219 seed variety, MR220CL2 seed variety, planting technology, broadcasting technology, application of agrochemicals and harvesting technology had a negative effect on technical inefficiency. From the estimates age positively affect technical inefficiency, implying that farmers who are older are more inefficient (less efficient). This could be possible as ageing farmers are less energetic to work on farm and may likely lower their technical efficiency. It is also possible that older farmers could be more traditional and conservative and therefore show less willingness to adopt new practices. [16] argue that the influence of age on technical efficiency is relative to the empirical data being analysed. Age can only influence technical efficiency positively if the older farmers gain experience to know the best practices. On the other way, age can influence 
technical efficiency negatively if the farmers are unwilling to take risk to adopt the best farm practices. However, the finding is consistent with study of [19].

Experience is the best teacher. Thus, the longer a person stays on a job, the more likely the person is to become an expert. Farming involves a lot of risks and uncertainties, hence, to be competent enough to handle all the unexpected changes of farming a farmer must have stayed on the farm for quite some time. A farmer who has been growing paddy for many years is likely to be more knowledgeable about the pattern of rainfall, the incidence of pest and diseases, and other agronomic conditions of the area than a farmer who is just coming into the business irrespective of their level of education. Result of the analysis shows that experience negatively affects technical inefficiency implying that the more the farmer experience the less inefficiency. This result is consistence with the findings of [21] and[25].

Table 6: Maximum Likelihood estimates for parameters of the Inefficiency effects Model of trans-log production function.

\begin{tabular}{|lllll|}
\hline Variable & Parameter & Coefficient & Std. Error & P - Value \\
\hline Constant & $\square_{0}$ & $-3.454^{* * *}$ & 1.160 & 0.003 \\
Age & $\square_{1}$ & 0.001 & 0.110 & 0.990 \\
Education & $\square_{2}$ & -0.002 & 0.007 & 0.729 \\
Marital Status & $\square_{3}$ & 1.107 & 1.123 & 0.354 \\
Household Size & $\square_{4}$ & 0.038 & 0.048 & 0.429 \\
Farming Experience & $\square_{5}$ & -0.0002 & 0.008 & 0.976 \\
Extension Visit & $\square_{6}$ & $-0.042^{* * *}$ & 0.012 & 0.000 \\
Credit Access & $\square_{7}$ & $-2.194^{*}$ & 1.199 & 0.069 \\
Location(State) & $\square_{8}$ & 0.996 & 1.144 & 0.384 \\
Land Cultivation Tech. & $\square_{9}$ & -0.001 & 0.009 & 0.883 \\
MR219 Seed Variety & $\square_{10}$ & $-3.356^{*}$ & 1.907 & 0.054 \\
MR220CL2 Seed Var. & $\square_{11}$ & $-3.628^{* *}$ & 1.578 & 0.020 \\
Planting Tech. & $\square_{12}$ & -0.072 & 0.233 & 0.758 \\
Broadcasting Tech. & $\square_{13}$ & $-0.505^{* *}$ & 0.207 & 0.014 \\
Agrochemicals Tech use & $\square_{14}$ & -1.042 & 2.331 & 0.665 \\
& & & &
\end{tabular}




\begin{tabular}{|lllll} 
Harvesting Tech. $\quad \square_{15}$ & $-0.011^{* *}$ & 0.005 & 0.012
\end{tabular}

Source:Field Survey, 2016.Note: *, ** and *** denote significance at $10 \%$ and $5 \%$ and $1 \%$ level respectively.

The coefficient of household size is positive. This signifies that as the household size increases farmers technical efficiency reduces. This agrees with [26] and [27] who reported that family size have a negative influence on famers productivity. In a situation where the family size is large and only a small proportion of farm labour is derived from it, then the inefficiency effect are expected to be greater. The coefficient of education was negative. This by implication implies that higher level of education increase their chances of using improved and sophisticated technology and techniques which requires training and reading manuals and has attendance increase in yield and optimum use of inputs resources. This result is consistence with the findings of [28]; [29] and [30]. The estimated coefficient of farmer`s access to credit was negative. This implies that the use of credit could decrease the inefficiency effect to production. On the other hand, farmers who had used the credit was having the greater efficiency since farmers with less liquidity constraints may obligate the farms to use the optimal input and thereby closed to optimal output. This result is in full agreement with finding of [31] and [7].

According to [32], extension visits to farmers enable them to use recommended cultural practices in a production to improve upon their efficiency. Extension agents are supposed to provide advisory services and training of farmers to improve upon their efficiency. According to the result, this variable negatively affects inefficiency and by implication it means that the more the farmer acquired knowledge from the extension services the more the farmer become less inefficient. The observed result is consistence with the finding of [6]. The type of seed planted by the producer whether improve or local to a large extent determines the harvest. The improved varieties are expected to yield more than the local variety [33]. Therefore, the type of seed planted is expected to influence the level of paddy farm efficiency. All farmers in the study area used improve seed variety which belongs to either MR219 or MR220CL2. The findings of the parameter estimates of seed technology confirm with apriori expectation as both MR219 and MR220CL2 negatively affects technical inefficiency and are significant at 5\% level respectively. This implies that use of improve seed could reduce farm technical inefficiency.

Planting method captures whether a farmer employed broadcasting or transplanting method for the production. From the result farmers who adopted broadcasting method are less inefficient compared to those who use transplanting method. The estimated parameter reveals that planting method negatively affects farm inefficiency. This indicates that planting method employed by the farmers (broadcasting) reduces inefficiency compared to transplanting means of planting. On the other hand, machine or manual broadcasting method used by the producers influences their efficiency. The finding shows that machine broadcast reduces inefficiency compared to manual broadcast. The parameter coefficient is significant at 5\% and negatively related to inefficiency. This finding is consistent with work of [24]. The analysis on agrochemicals usage by the producers reveals that agrochemical increases the efficiency of the farms as it has negative relationship with inefficiency. Furthermore, result from the harvesting method employed reveals 
that farmers harvesting with machine were more efficient than those who did manual harvesting. The coefficient of the parameter is significant at $5 \%$ and negatively related with inefficiency.

\subsection{Distributions of estimated technical efficiency}

The average farm-level technical efficiencies of paddy farmers were predicted for the stochastic frontier specification model and segregated into three: Perlis and Kedah States and also for the whole MADA area. The estimates are presented in Table 7. On the Overall columns, the mean technical efficiency is approximately 0.836 , implying that the average farm produced only 83.6 percent of the maximum attainable output for a given input levels for the period of production under analysis. It also implies that there still exist 16.4 percent potential for increasing the output of decision making units (DMUs) simply by adopting a technology of the best-practice DMUs.

Table 7: Distribution of Technical Efficiency Estimated with Flexible Risk Specification Model

\begin{tabular}{|lcccccc|}
\hline Efficiency Score & Perlis & \multicolumn{3}{c}{ Kedah } & \multicolumn{3}{c|}{ Overall } \\
& Freq. & $\%$ & Freq. & $\%$ & Freq. & $\%$ \\
\hline 1.00 & 0 & 0.00 & 0 & 0.00 & 0 & 0.00 \\
$>0.90<1$ & 23 & 27.40 & 93 & 29.70 & 116 & 29.20 \\
$>0.80 \leq 90$ & 28 & 33.30 & 62 & 19.80 & 90 & 22.70 \\
$>0.70 \leq 0.80$ & 20 & 23.80 & 82 & 26.20 & 102 & 25.70 \\
$>0.60 \leq 0.70$ & 10 & 11.90 & 41 & 13.10 & 51 & 12.80 \\
$>0.50 \leq 0.60$ & 2 & 2.40 & 30 & 9.60 & 32 & 8.10 \\
$>0.40 \leq 0.50$ & 1 & 1.20 & 5 & 1.60 & 6 & 1.50 \\
Total & 84 & 100 & 313 & 100 & 397 & 100 \\
Mean & $\mathbf{0 . 8 6 6}$ & & $\mathbf{0 . 8 2 2}$ & & $\mathbf{0 . 8 3 6}$ & \\
Minimum & 0.602 & & 0.407 & & 0.407 & \\
Maximum & 0.998 & & 0.999 & & 0.999 & \\
Std. Dev. & 0.099 & & 0.138 & & 0.132 & \\
\hline
\end{tabular}

Source: Author computation from field survey data, 2016

The highest estimated technical efficiency is 0.999 and the lowest is 0.407 . In the present study, approximately $23 \%$ of the sample farmers had a mean technical efficiency greater than 80 or equal to 90 percent, $29 \%$ had a mean technical efficiency above 90 percent, $26 \%$ had mean 
technical efficiency more than 70 or equal to 80 percent, $21 \%$ had greater than 50 or equal to 70 percent while the $2 \%$ operating on mean technical efficiency of greater than 40 or equal $50 \%$ were those who were badly affected by various factors ranging from technical production constraints, socio-economic and environmental factors. The estimated technical efficiency score for paddy farmers in Perlis State varies from 0.602 to 0.998 with an average score of 0.866 . However, that of Kedah State ranges from 0.407 to 0.999 with an average of 0.822 . The finding indicates that farmers in Perlis state are more efficient than their counterpart in Kedah State.

\section{CONCLUSIONS}

The study engaged the use of stochastic frontier model with flexible risk specifications base on[12] model modified by [14] to a farm level data obtained from a sample of 397 paddy producers in Muda Agricultural Development Authority (MADA), in an effort to appropriately understand paddy production process. A single stage maximization of the model using frontier available in Stata12 software provides estimates of the stochastic frontier model with flexible properties composed of the mean output, production risk and inefficiency models.Results from the analysis recommend that technical inefficiency enhances the variability of paddy production in MADA. However, according to the modelestimates Output variability is explained mainly by technical inefficiency and production risk.The present study demonstrates that due to the uncertainty associated with agricultural production processes, such as crops and the paddy in general, the theoretical frame work for investigating technical efficiency needs to be extended to incorporate production risk. However, estimation of technical efficiency of paddy farms under the assumption of risk neutrality with respect to production risk in inputs fundamentally incorporates biased estimates of the technical efficiency of the farms. Hence, such bias estimates might lead to misleading policy recommendations judging from the results of this study.

\section{ACKNOWLEDGMENT}

This study was supported by LRGS Food Security: Enhancing Sustainable Rice Production through Innovation Research, Vot No. 5525017.

\section{REFERENCES}

[1] M. D. M. Mohd, R. R., \& Shah, "Food and livelihood security of the Malaysian paddy farmers," Econ. Technol. Manag. Rev., vol. 8, pp. 59-69, 2013.

[2] MOA \& AI, "Perangkaan Padi Malaysia-Jabatan Pertanian, Ministry of Agriculture and Agro-Based Industry," Ministry of Agriculture and Agro-Based Industry, 2014. .

[3] M. M. . Najim, T. . Lee, M. . Haque, and M. Esham, "Sustainability of Rice Production: a Malaysian Perspective," J. Agric. Sci., vol. 3, no. 1, pp. 1-12, 2007.

[4] G. Siwar, C., Idris, N. D. M., Yasar, M., \& Morshed, "Issues and Challenges facing rice production and food security in the granary areas in the East Coast Economic Region (ECER), Malaysia.," Res. J. Appl. Sci. Eng. Technol., vol. 7, no. 4, pp. 711-722, 2014.

[5] R. Alias and L. Ismail, "Estimating Economic Efficiency in Paddy Farms: A Case of Northwest Selangor IADP," Pertanika J. Soc. Sci. Humanit., vol. 4, no. 1, pp. 77-82, 1996.

[6] Z. Mailena, L., Shamsudin, M. N., Radam, A., \& Mohamed, "Efficiency of Rice Farms and its Determinants: Application of Stochastic Frontier Analysis," Trends Appl. Sci. Res., 
vol. 9, no. 7, pp. 360-371, 2014.

[7] I. M. M. and H. M. Ghee-Thean L, "Measuring Technical Efficiency of Malaysian Paddy Farming: An application of Stochastic Frontier Approach," J. Appl. Sci., vol. 15, no. 12, pp. 1602-1607, 2012.

[8] R. Kamaruddin, J. Ali, and N. M. Saad, "Happiness and its influencing factors among paddy farmers in granary area of Mada," World Appl. Sci. J., vol. 28, no. 13, pp. 91-99, 2013.

[9] Rafidah A., "GIS Base Paddy Maturity Monitoring Supporting System,” 2011.

[10] P. Aigner, D., Lovell, C. K., \& Schmidt, "Formulation and Estimation of Stochastic Frontier Production Function Models," J. Econom., vol. 6, no. 1977, pp. 21-37, 1977.

[11] J. Meeusen, W., \& Van den Broeck, "Efficiency estimation from Cobb-Douglas production functions with composed error," Int. Econ. Rev. (Philadelphia)., pp. 335-444, 1977.

[12] Just R.E and Pope R.D, "Stochastic Specification of Production Functions and Economic Implications*," J. Econom., vol. 7, no. 488, pp. 67-86, 1978.

[13] G. H. Battese, G. E., Rambaldi, A. N., \& Wan, "A stochastic frontier production function with flexible risk properties," J. Product. Anal., vol. 8, no. 1997, pp. 269-280, 1997.

[14] S. C. Kumbhakar, "Specification and Estimation of Production Risk, Risk Preferences and Technical Efficiency," Am. J. Agric. Econ., vol. 84, no. 1, pp. 8-22, 2002.

[15] T. J. Battese, G. E., \& Coelli, "Prediction of Firm-Level Technical Efficiencies with a Generalized Frontier Production Function and Panel Data," J. Econom., vol. 38, no. 1988, pp. 387-399, 1988.

[16] R. Villano and E. Fleming, "Technical Inefficiency and Production Risk in Rice Farming: Evidence from Central Luzon Philippines*," Asian Econ. J., vol. 20, no. 1, pp. 29-46, Mar. 2006.

[17] K. Chakraborty, S. Misra, and P. Johnson, "Cotton farmers' technical efficiency: Stochastic and nonstochastic production function approaches," Agric. Resour. Econ. Rev., vol. 31, no. 2, pp. 211-220, 2002.

[18] A. I. a. and O. R. A. Ambali O.I., Adegbite D. A., "Comparative Analysis of Technical Efficiency of Beneficiary and Non-Beneficiary Food Crop Farmers of Bank of Agriculture in Ogun State, Nigeria," ARPN J. Agric. Biol. Sci., vol. 7, no. 12, pp. 1038-1047, 2012.

[19] K. Ogundari, "Resource-productivity, allocative efficiency and determinants of technical efficiency of rainfed rice farmers: A guide for food security policy in Nigeria," Agric. Econ., vol. 54, no. 5, pp. 224-233, 2008.

[20] S. I. Dlamini, M. B. Masuku, and J. I. Rugambisa, "Technical efficiency of maize production in Swaziland: A stochastic frontier approach," African J. Agric. Res., vol. 7, no. 42, pp. 5628-5636, 2012.

[21] O. O. Ogundari, K., \& Akinbogun, "Modeling Technical Efficiency with Production Risk: A Study of Fish Farms in Nigeria," Mar. Resour. Econ., vol. 25, no. 3, pp. 295-308, 2010.

[22] A. J. Picazo-Tadeo and A. Wall, "Production risk, risk aversion and the determination of risk attitudes among Spanish rice producers," Agric. Econ., vol. 42, no. 4, pp. 451-464, 2011.

[23] T. Tiedemann and U. Latacz-Lohmann, "Production Risk and Technical Efficiency in Organic and Conventional Agriculture - The Case of Arable Farms in Germany," J. Agric. 
Econ., vol. 64, no. 1, pp. 73-96, 2013.

[24] Adinku E.O, "Production Risk and Technical Efficiency of Irrigated Rice Farms in the Greater Accra and Volta Regions of Ghana (Doctoral dissertation, University of Ghana).," 2013.

[25] M. E. Alam, M. M., Siwar, C., Talib, B., \& bin Toriman, "The Relationships between the Socio-Economic Profile of Farmers and Paddy Productivity in North-West Selangor, Malaysia," Asia-Pacific Dev. J., vol. 18, no. 1, pp. 161-173, 2011.

[26] I. Okike, "Crop-livestock interactions and economic efficiency of farmers in the savanna zones of Nigeria. Unpublished PhD thesis, University of Ibadan, Ibadan, Nigeria," 2000.

[27] Yusuf S.A and O. Malomo, "Technical Efficiency of Poultry Production in Ogun State: A Data Envelopment Analysi (DEA) Approach," Int. J. Poult. Sci., vol. 6, no. 9, pp. 622629, 2007.

[28] Amaza P.S and Maurice D. C, "Identification of Factors that Influence Technical Efficiency in Rice-Base Production Systems in Nigerian," 2005.

[29] A. Muhammad-Lawal, A., Omotesho, O. A., \& Falola, "Technical Efficiency of Youth Participation in Agriculture: A case Study of the Youth-in-Agriculture Programme in Edo State, South Western Nigeria," Niger. J. Agric. Food Environ., vol. 5, no. 1, pp. 20-26, 2009.

[30] Z. Oladimeji Y. U., \& Abdulsalam, "Analysis of Technical Efficiency and Its Determinants among Small Scale Rice Farmers in Patigi Local Government Area of Kwara State, Nigeria," IOSR J. Agric. Vet. Sci., vol. 3, no. 3, pp. 34-39, 2013.

[31] B. E. Bravo-Ureta and A. E. Pinheiro, "Efficiency analysis of developing country agriculture: A review of the frontier function literature," Agric. Resour. Econ. Rev., vol. 22, no. 1, pp. 88-101, 1993.

[32] S. Al-hassan, "Technical Efficiency of Rice Farmers in Northern Ghana," 2008.

[33] Fakayode S. B, "Technical Efficiency and Factor Productivity in Upland and Lowland Rice Production Systems in Kwara State, Nigeria," 2009. 